DOI: $10.20472 / B M C .2017 .005 .003$

\author{
JURAJ FABUS \\ Zilinska univerzita v Ziline, Slovak Republic \\ IVETA KREMENOVA \\ Zilinska univerzita v Ziline, Slovak Republic \\ VIKTORIA FABUSOVA \\ Zilinska univerzita v Ziline, Slovak Republic
}

\title{
THE USAGE OF THE OPEN DATA IN THE BUSINESS MANAGEMENT
}

\begin{abstract}
:
This paper focuses on the issue of open data in the business management. All information and data on which the open data application operates, is drawn from publicly available databases and registries. Basic information frame is formed by the digital structured data, files in pdf, csv, xls formats and electronic scans of various documents. The research focuses on the comparison of applications (mainly Finstat and Indexpodnikatela) possibilities to search open data that contain information about companies in the Slovak Republic area. For the purposes of this paper, we present the specific examples of searching information through a filter provided by individual applications. The filters differ from each other, as well as individual displayed data.
\end{abstract}

\section{Keywords:}

Open data, FinStat, IndexPodnikatela, information searching

JEL Classification: C88, L17, L25 


\section{Introduction}

This paper focuses on the issue of open data in the business management. The research focuses on the comparison of applications possibilities to search open data that contain information about companies in the Slovak Republic area. For the purposes of this paper, we present the specific examples of searching information through a filter provided by individual applications.

\section{Open data}

Management (or managing) is the administration of an organization, whether it be a business, a not-for-profit organization, or government body (Stofkova, 2011). Management includes the activities of setting the strategy of an organization and coordinating the efforts of its employees or volunteers to accomplish its objectives through the application of available resources, such as financial, natural, technological, and human resources. The term "management" may also refer to the people who manage an organization.

Open data is the idea that some data should be freely available to everyone to use and republish as they wish, without restrictions from copyright, patents or other mechanisms of control (Auer, 2007). The goals of the open data movement are similar to those of other "open" movements such as open source, open hardware, open content and open access.

The concept of open data is not new; but a formalized definition is relatively new-the primary such formalization being that in the Open Definition which can be summarized in the statement that "A piece of data is open if anyone is free to use, reuse, and redistribute it - subject only, at most, to the requirement to attribute and/or share-alike. (opendefinition.org)"

Open data may include non-textual material such as maps, genomes, connectomes, chemical compounds, mathematical and scientific formulae, medical data and practice, bioscience and biodiversity. Problems often arise because these are commercially valuable or can be aggregated into works of value. Access to, or re-use of, the data is controlled by organisations, both public and private. Control may be through access restrictions, licenses, copyright, patents and charges for access or reuse. Advocates of open data argue that these restrictions are against the communal good and that these data should be made available without restriction or fee. In addition, it is important that the data are re-usable without requiring further permission, though the types of re-use (such as the creation of derivative works) may be controlled by a license.

These are for example timetables, states incomes, budget, databases, list of providers of social services, register of organizations, lists of debtors or the measurement of air pollution. 
A typical depiction of the need for open data:

Numerous scientists have pointed out the irony that right at the historical moment when we have the technologies to permit worldwide availability and distributed process of scientific data, broadening collaboration and accelerating the pace and depth of discovery, but we are busy locking up that data and preventing the use of correspondingly advanced technologies on knowledge (Wilbanks, 2008).

Sources of open data are:

- the state and public administration,

- schools and universities,

- non-profit organizations, associations,

- private companies.

We focus in this paper on two applications that provide information about businesses in the Slovak Republic area. The first is IndexPodnikatela (indexpodnikatela.sk) and the second application is FinStat (finstat.sk). For comparison purposes, we closer identify the parameters of the Slovak corporate market.

Figure 1: Rankings for Europe and Central Asia
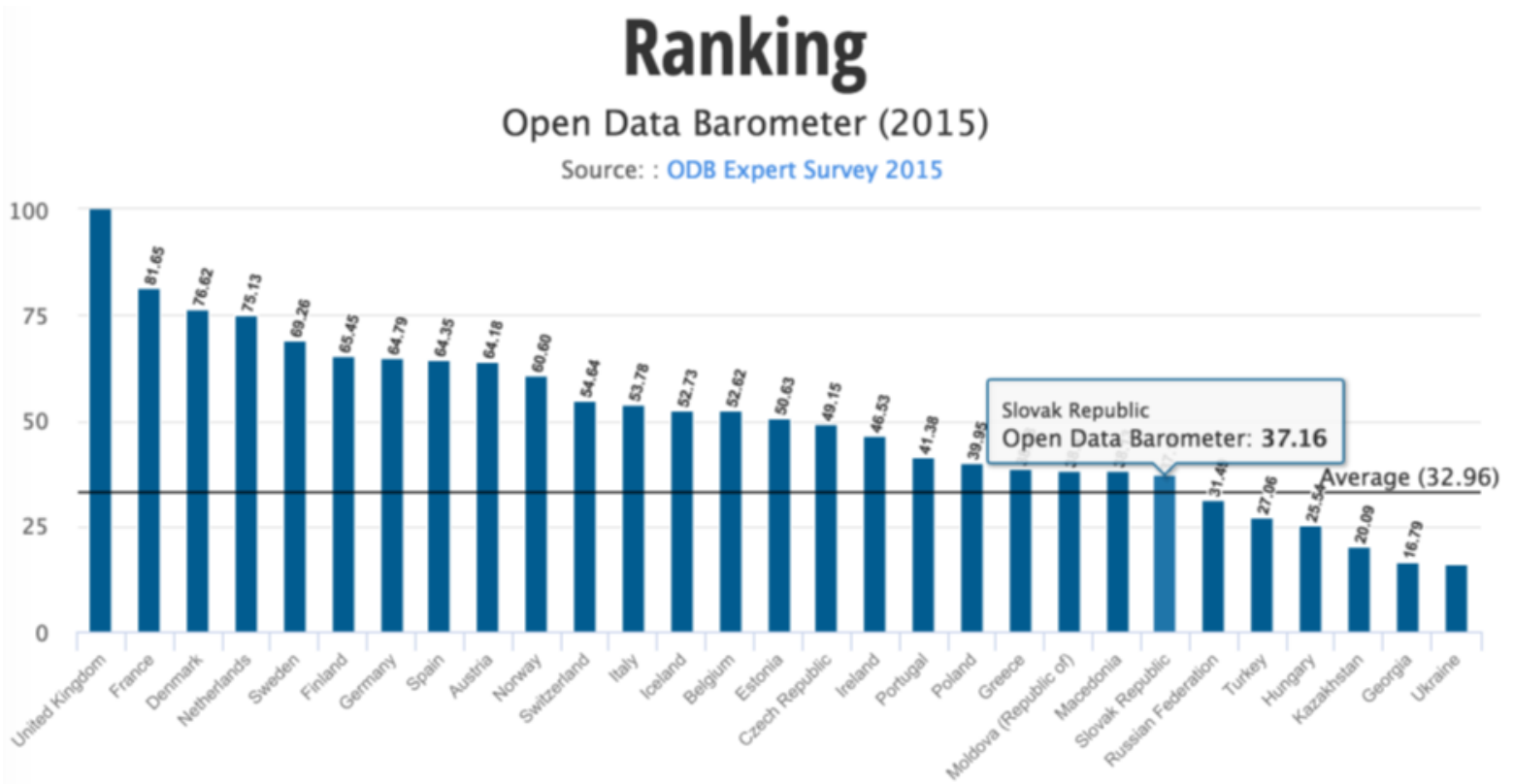

Source: Own adjustment based on Open Data Barometer [online: http://opendatabarometer.org/]

We can see in figure 1 the Slovakia's position in Open Data Barometer scale.

Produced by the World Wide Web Foundation as a collaborative work of the Open Data for Development (OD4D) network and with the support of the Omidyar Network, the Open Data Barometer (ODB) aims to uncover the true prevalence and impact of open data initiatives around the world. It analyses global trends, and provides comparative data on countries and regions using an in-depth methodology that combines contextual data, technical assessments and secondary indicators. 
Covering 92 countries in the present edition, the Barometer ranks nations on:

- Readiness for open data initiatives.

- Implementation of open data programmes.

- Impact that open data is having on business, politics and civil society.

The Barometer is a truly global and collaborative effort, with input from more than 150 researchers and government representatives. It takes over six months and more than 9,000 hours of research work to compile. This report is intended to be a summary of some of the most striking findings. The full data is available online, and intended to support further secondary research into the progression of open data policies and practices across the world.

Slovakia has achieved above-average ranking. There are 5.5 million inhabitants, of which more than 337,000 are self-employed. More than 290,000 are registered companies. We can say that the data from the Statistical Office are outdated, since they are published for the year 2015. We can obtain updated information from already mentioned applications IndexPodnikatel'a and FinStat. These applications have their own databases and information is available immediately. Database contains information on defunct and newly established companies and self-employees. In the table below, we can see a comparison of databases of two selected applications.

Table 1: Databases comparison

\begin{tabular}{|l|l|l|}
\hline Application & FinStat & IndexPodnikatel'a \\
\hline The number of companies & 410028 & 334622 \\
\hline The number of self-employees & 815977 & 1015354 \\
\hline
\end{tabular}

Source: Own processing.

To another database, which application FinStat contains, belong a database of financial data, a database of persons in the companies, a database of nonprofit organisations. After paying fees there is also a database of Czech companies and self-employees, legal databases (e.g. register of executions and payment orders) and other databases containing information from commercial journal (eg auctions).

Application IndexPodnikatela contains the following additional databases: a database of accountig statements, a database of financial analysis, a database of records from commercial journal, a database of debtors in taxes, debtors on social and health insurance.

Among published business data belong:

- registers of self employees, companies and organizations - Commercial Register is a public register, which includes statutory data about entrepreneurs and other persons, which are stipulated by a special law,

- macroeconomic, demographic and social statistics,

- economic results of companies - incomes, profits, etc., 
- public procurement and e-marketplace,

- central register of contracts,

- a list of Slovak domains,

- contact information, company websites, catalogs,

- debtors' list (health and social insurance, taxes, duties, state claims),

- entrepreneurs in bankruptcy (bankruptcy, restructuring, small bankruptcies),

- execution proceedings,

- judicial decisions,

- register of pledges,

- information from the cadastre (land, buildings, certificates of ownership, encumbrances).

These data can be used in business. The entrepreneurs may know better the market in which they operate, for example: how many companies are operating in the same industry, or area, what turnover they have. The enterpreneurs may properly identify risks in the market and in the business contact (Soltes, 2016). Available information gives them an idea about their business partners. Applications, which are compared below, inform also about the changes in the monitored companies (bankruptcy, execution proceedings). Based on the data, which can be obtained from the applications, the company can compare its results with the competition, or branch, etc. And on this basis it can take improvement, or gain new business oportunities.

Examples of what data we can watch:

- results of competitors,

- the change of the name or residence of the company,

- if the company became a VAT payer,

- if the company has been declared bankrupt or restructuring,

- increasing debt of the company,

- the change of the owner or manager of the company,

- if the company rewrites properties to other persons / companies,

- if the property is on mortgage,

- if the company has made any contracts with the state.

\section{FinStat}

FinStat was founded in 2012 and launched in 2013. The aim of the application was to create a web portal that helps people to easily and for free assess the financial health of Slovak companies.

FinStat has processed from the beginning a number of data sources which analyzes and uses to make a picture of an individual companies. By combining data sources, editing and analyzing them it creates at the same time the image of the entire market Slovak companies as a whole, individual sectors and groups of entrepreneurs. 
The most important data sources, which are processed, are commercial bulletin, business register, trade register, the register of statement of finances, lists of debtors from insurance companies, lists of financial administrative and judicial decisions. Thre are also other data sources, which are used by FinStat.

\section{IndexPodnikatel'a}

The project IndexPodnikatel'a has been created as a tool to promote and develop a transparent business environment in Slovakia. It is an innovative and unique service that can examine and analyze any company doing business in Slovakia. Entrepreneurs can therefore receive the basic and extended information about business partners, suppliers or competitors. IndexPodnikatel'a provides a detailed view of the arrears of health and social insurance, tax, bankruptcy, restructuring, execution and other statements relating to the monitoring company. One of the most important outcomes of this service is also a financial analysis of the company and the index "IndexPodnikatela".

All information and data on which the IndexPodnikatela operates is drawn from publicly available databases and registries. Basic information frame is formed by the digital structured data, files in pdf, csv, xls formats and electronic scans of various documents. Detailed analysis of companies requires detailed information about financial results (financial statements) for the previous periods. They are the only one in Slovakia, who decided to digitize (convert into a structured format) all qualitative sufficient and for the processing suitable documents (scans of accounting documents). From the vast amount of data they create financial analysis of companies, predictions, but also various statistical analyzes relating to the sectors, or specific lines of business.

Not every enterpreneur, self-employees, or sales representative may understand the variety of financial and economic indicators and financial analysis. Therefore, on the basis of the data received, the index Podnikatela decided to evaluate the reliability and performance of companies, by creating the indexPodnikatel'a, which clearly shows in which financial and economic state the company is, and whether it is appropriate to establish a business relationship.

With IndexPodnikatela you can immediately verify your prospective business partner and add him to the list of monitored companies. If any problems or changes occur the system notifies you via automatic notification.

Both applications offer services for free as well as the paid services.

\section{Specific examples for searching information}

For the purposes of this paper, we present the specific examples of searching information through a filter provided by individual applications. The filters differ from each other, as well as individual displayed data. This is because the FinStat application uses activity in sector as a filter for entrepreneurial activity, and application IndexPodnikatel'a uses the field of business according to the specification SKNACE in 
the filter. In the FinStat application, we can see the classification by SKNACE only in the company details. Also, it is because the data that they present are from different periods of time.

In Figure 2 we can see the design of FinStat application and in Figure 3 we can see the design of IndexPodnikatela application and also filtered data. Figure 2 shows the output for search - traders in the information technology industry in Žilina region. Figure 3 shows the output for search - self-eployees in the business field of Information and Communication in Žilina region. We can observe a difference in filter from the beginning. FinStat application uses sectors to assign the activity of enterpreneur and IndexPodnikatel'a uses the branch of business according to SKNACE.

Figure 2: Searching in application FinStat

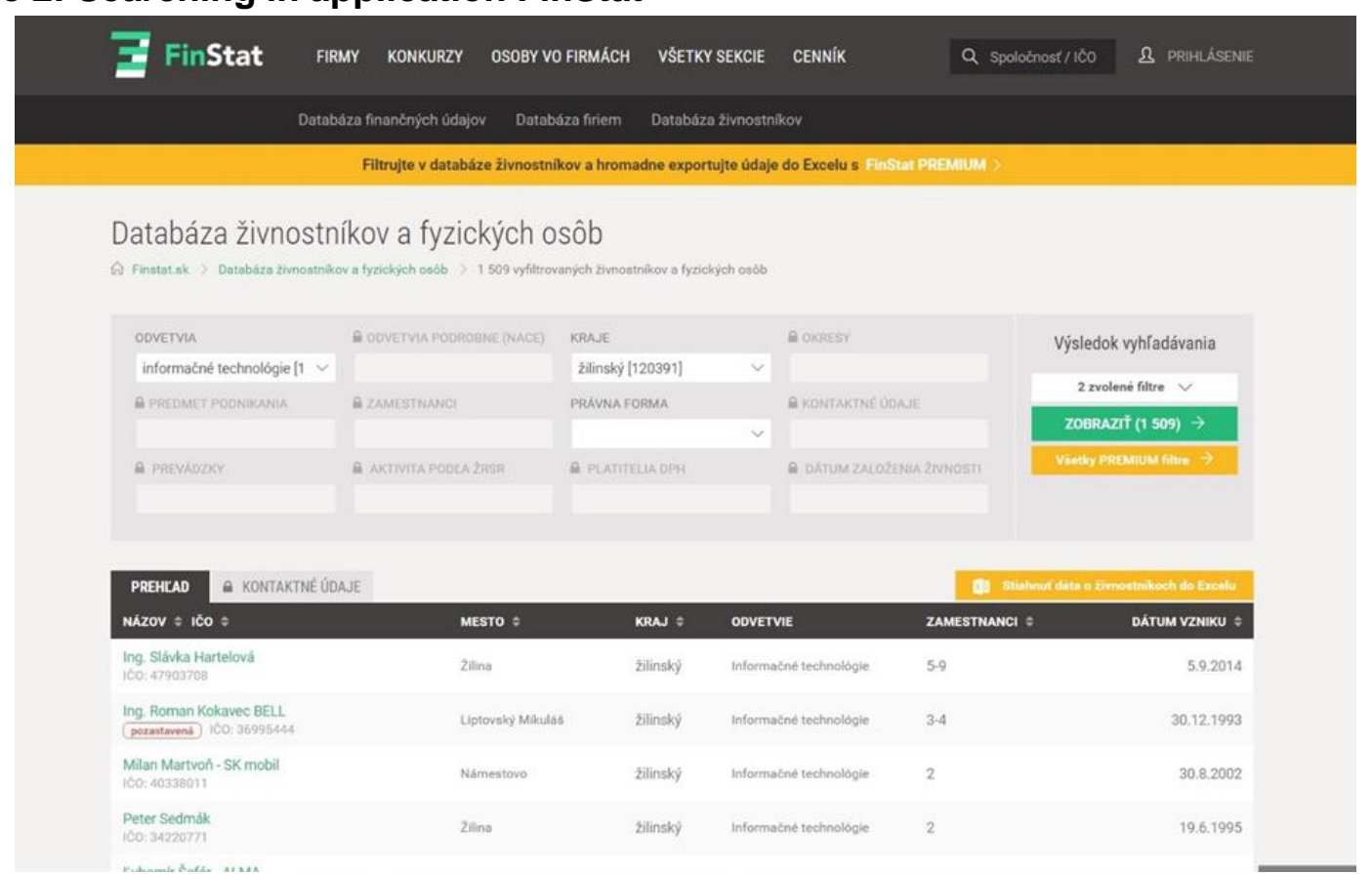

Source: Own processing. 
Figure 3: Searching in application IndexPodnikatel'a

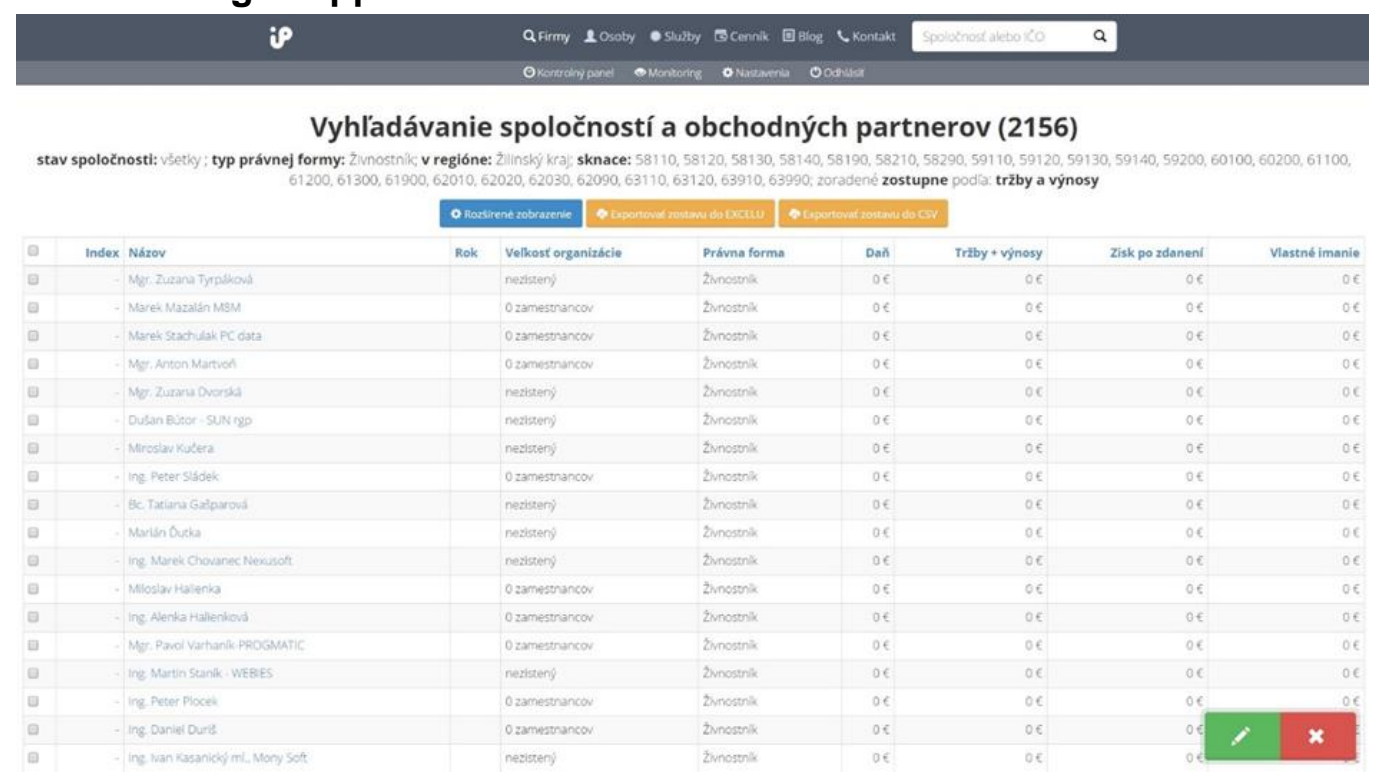

Source: Own processing.

Statistical Classification of Economic Activities (hereinafter "SKNACE") is given to categorize data relating to the economic entity as a statistical unit. It is one of the tools for the preparation of various statistics - outputs, inputs into the production process, capital formation and financial transactions of economic entities.

In Figures 4 and 5 we can see the filtered data. We searched for companies in the telecommunications industry in Žilina region. It was displayed the list of companies in the sector and a general information about these companies. The difference in displaying self-employees and companies is observed in the initial display of information on searching companies, i.e. we see the information about sales, profits, assets, etc.

Figure 4: The list of companies in Žilina region in telecommunication area in the application FinStat

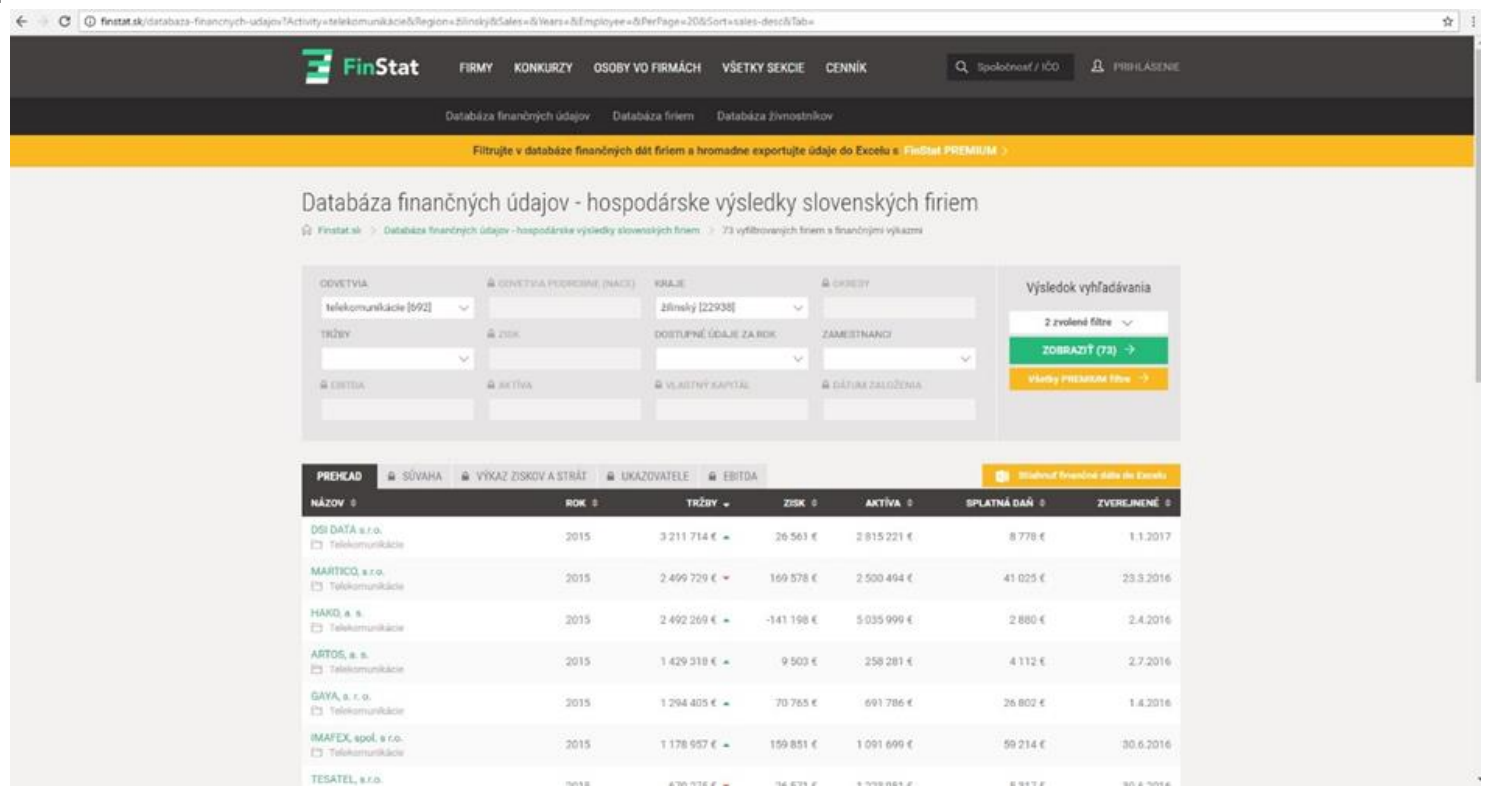

Source: Own processing. 
Figure 5: The list of companies in Žilina region in telecommunication area in the application IndexPodnikatel'a

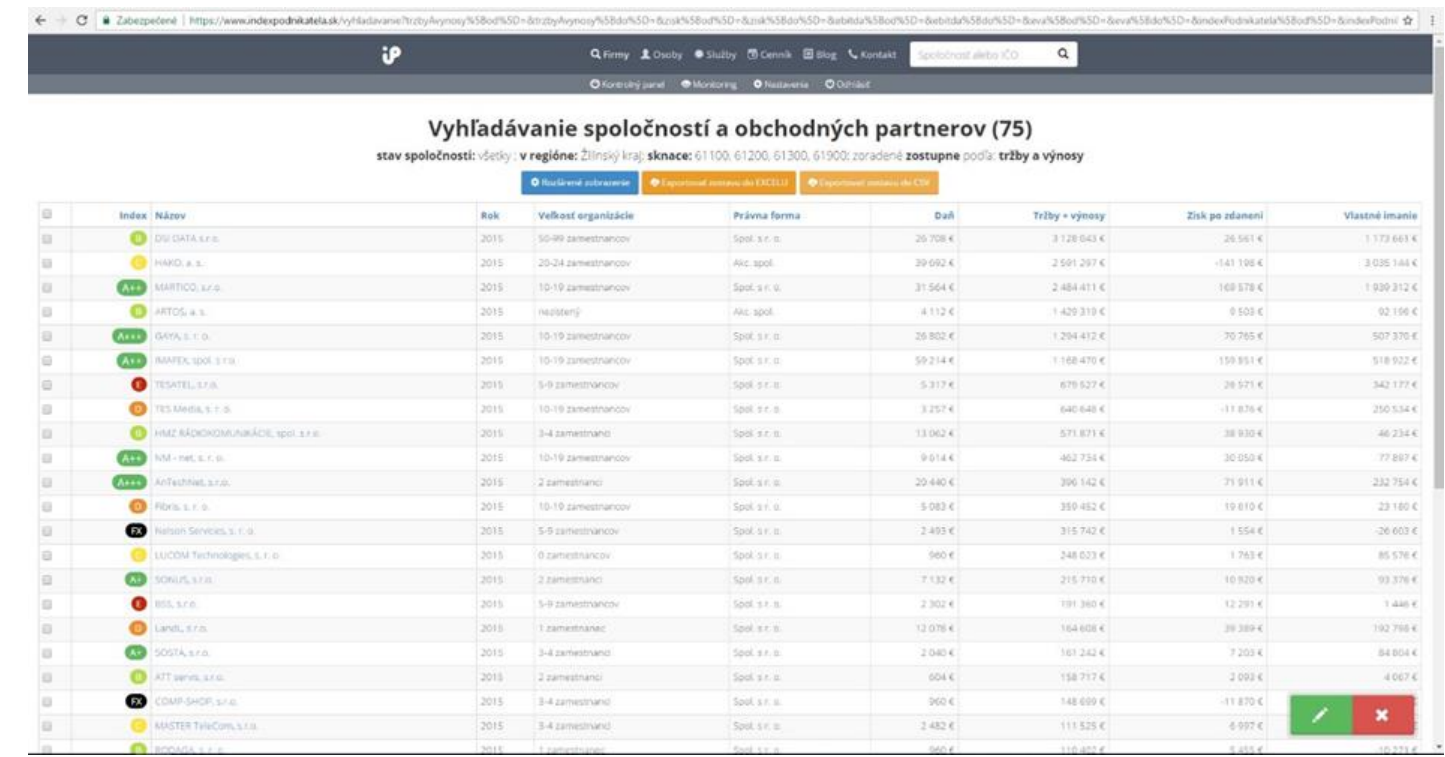

Source: Own processing.

If you click on a particular company, details about the company will be displayed, where we can find the necessary information regarding the company. Design of applications is different and also the way to get the searched information.

\section{Figure 6: Company details in FinStat application}

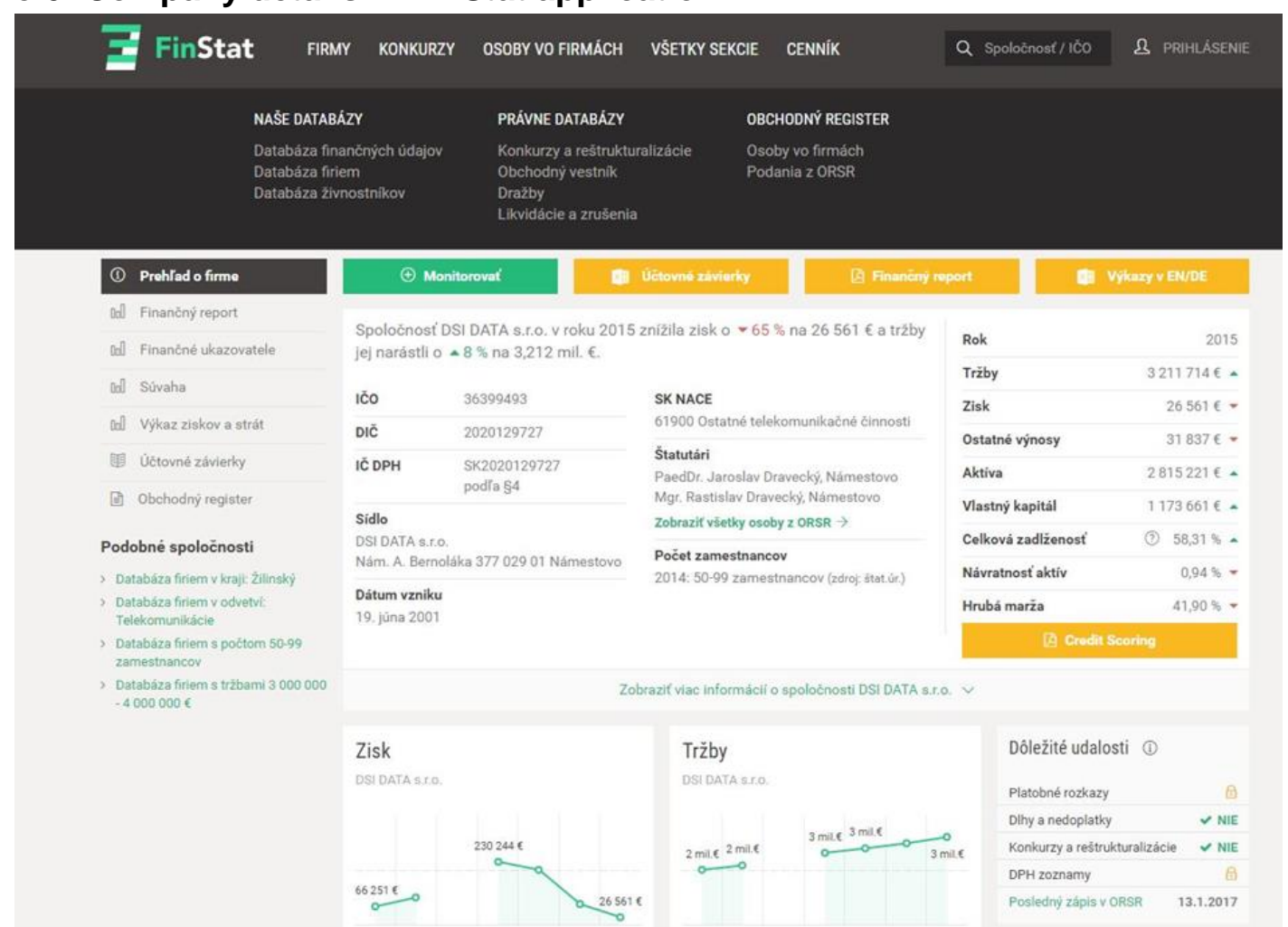

Source: Own processing. 
Figure 7: Assets and liabilities of selected company in FinStat application

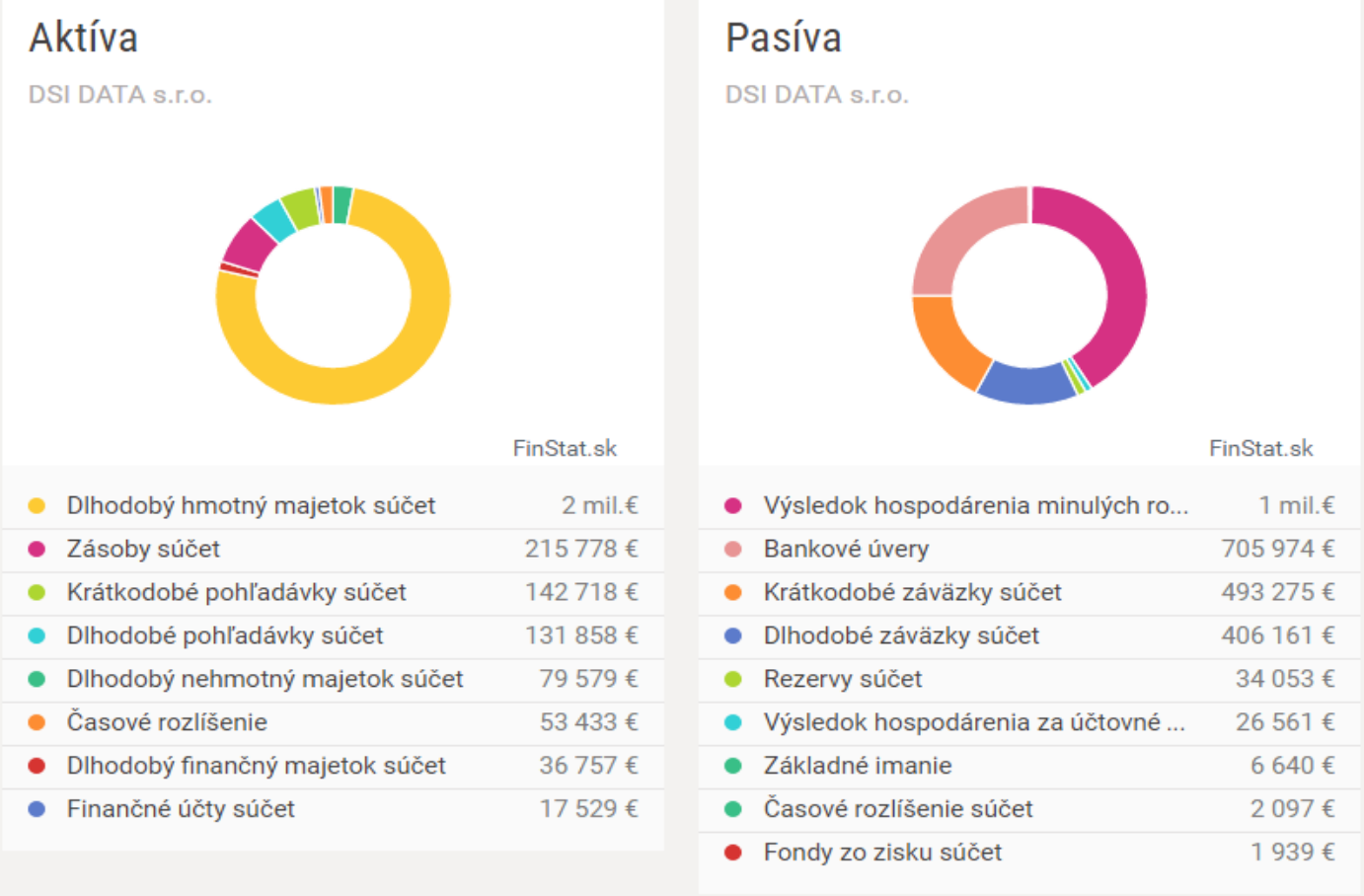

Source: Own processing.

In Figure 6, we can see an overview of information about a particular company in the FinStat application. There are data about incomes, profits, assets, liabilities (Figure 7), etc. for a specific year. These data can be converted to PDF. In the left panel, we can view the financial report, financial indicators, balance sheet, profit and loss statement and data from the commercial register of a particular company. In the upper bar are another options: monitoring of the company, financial statements, and the financial report, but these services are charged. 
Figure 8: Company Details in the application IndexPodnikatel'a

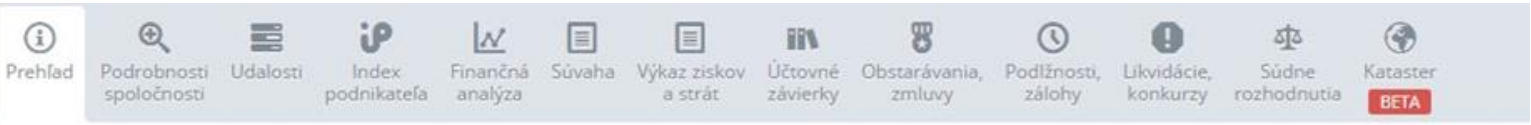

B DSI DATA s.r.o. - Prehliad firmy
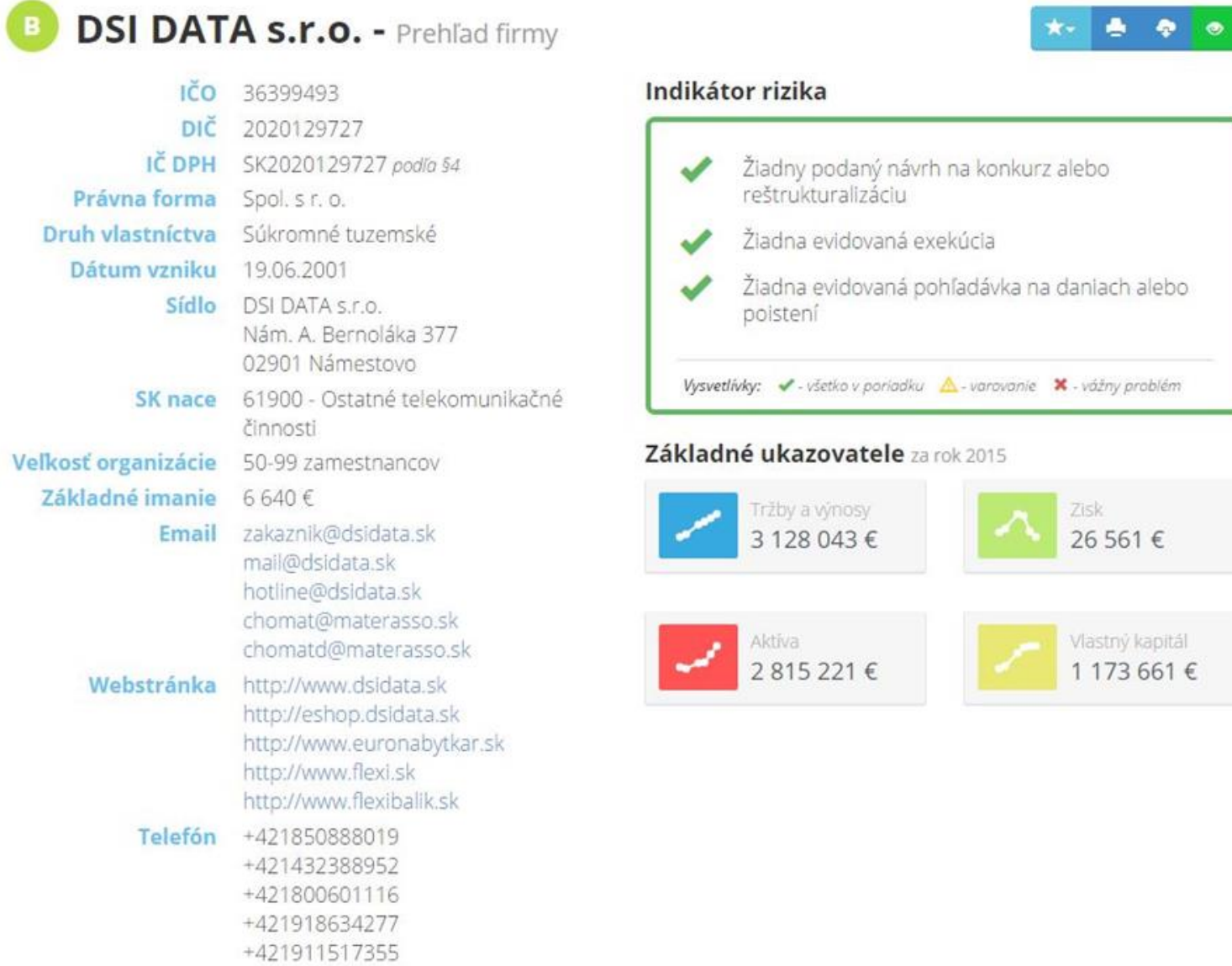

Indikátor rizika

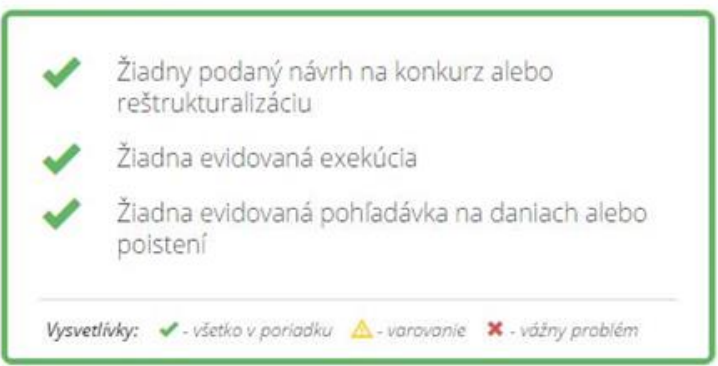

Základné ukazovatele za rok 2015

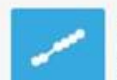

Source: Own processing.

In Figure 8, we can see an overview of a specific company in IndexPodnikatela application. In the top bar of the screen, we can gradually display more information about the specific company, events (Figure 9), index podnikatel'a (enterpreuer index), financial analysis (fraction of a financial analysis we can see in Figure 10), balance sheet, profit and loss account, financial statements, contracts and agreements, outstanding debts, liquidation and bankruptcy and court decisions. 
Figure 9: Detail of events related to the specific company in the application IndexPodnikatel'a

B DSI DATA s.r.o. - Udalosti

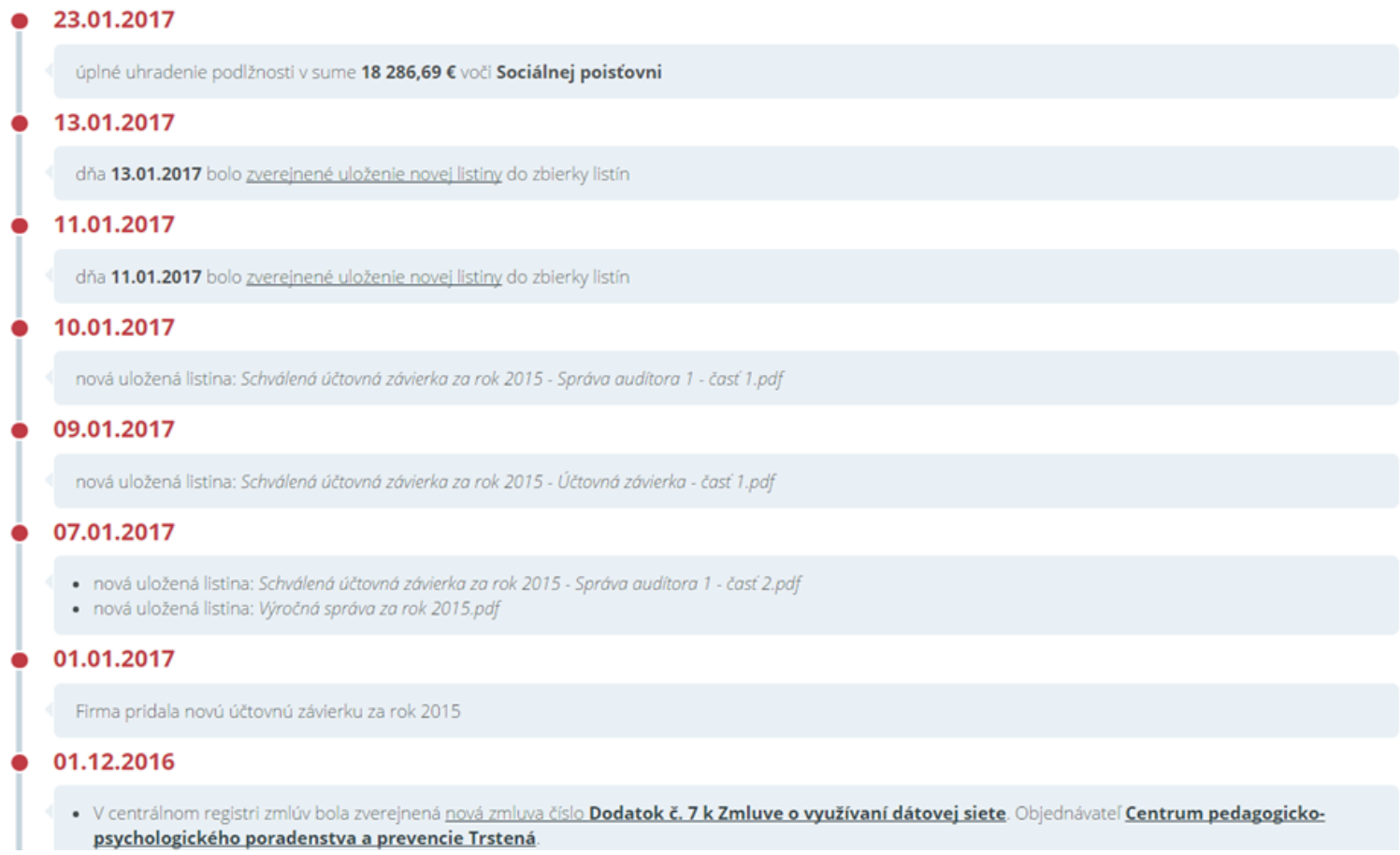

Source: Own processing.

Figure 10: Assets and liabilities of the specific company in the application IndexPodnikatel'a

\section{Vertikálna analýza}

Aktíva - Štruktúra obežných aktív

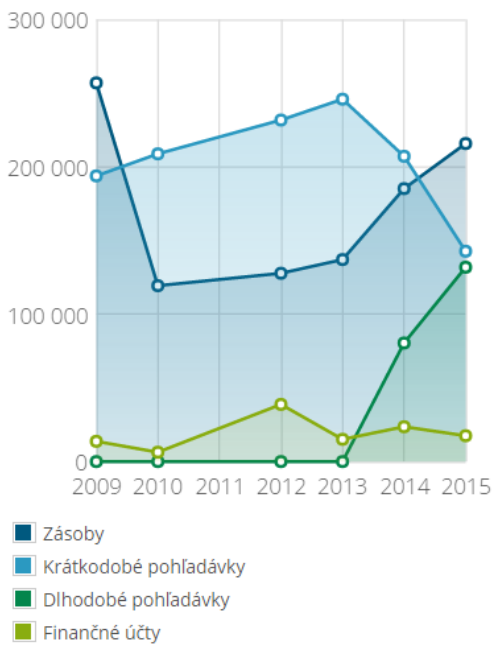

Aktíva - Štruktúra majetku

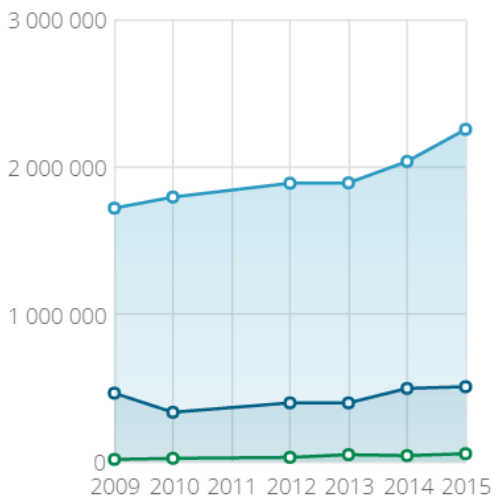

Obežný majetok

Neobežný majetok

Časové rozlíšnie
Pasíva - Štruktúra záväzkov

1000000

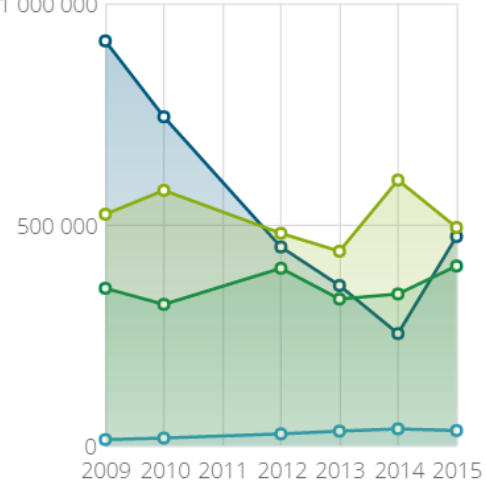

- Bankové úvery a finančné wyjpomoci

口ezery

Dlhodobé záväzky

[ Krátkodobé záväzky

Source: Own processing.

Since we did not obtain access to paid version of FinStat application, in the following paragraphs, we will describe only other features of IndexPodnikatel'a application, where we received a paid access. For the purpose of this paper we mention a specific 
example. We were looking for companies that sell wiring materials (SKNACE: 46520, 46690). Other information that we have obtained are:

- 1222 companies and 40 entrepreneurs carry business in this area,

- $66 \%$ of companies have a good credit rating,

- they place on the market goods for 9,033 companies (7158 traders and 1875 companies),

- $10 \%$ of companies have a high risk of bankruptcy and $11 \%$ have a medium risk.

If we take for an example a wiring works, we find out:

- thre is approximately 645 customers, which is $7.15 \%$ of the market

- $10 \%$ of companies in the market where the company supplying the goods has a high probability of bankruptcy,

- $1.7 \%$ of companies are in bankruptcy or restructuring,

- $6.6 \%$ of companies and sole traders has led debt.

- $0.5 \%$ of the companies is problematic in VAT paying,

- median period of the turnover in sector is 93 days for liabilities and 58 days for assets.

- The total indebtedness in the sector is $55 \%$.

Another feature of this application is people search, through which we can get also information about where is the person involved. We can see also the rating of individual companies. This function is used to gain insight into the financial health of all companies in which the searching person operates. The particular example can be seen in the Figure 11.

Figure 11: The participation of a particular person in application IndexPodnikatel'a searching

\section{Vyhl'adávanie osôb}

\begin{tabular}{|c|c|c|c|c|c|c|}
\hline & & \multicolumn{2}{|l|}{ Ladislav Bašternák @Bratislava } & \multicolumn{3}{|c|}{ Nájst osobu } \\
\hline & & Spoločnost & Funkcia & Rok & Tržby a výnosy & Zisk \\
\hline \multicolumn{7}{|c|}{ Ladislav Bašternák, Hodálová 3, Bratislava } \\
\hline & $\mathbf{x}$ & Konto invest s.r.o. & spoločník 100\% (minulý), konatel' (minulý) & & & \\
\hline (D) & $\checkmark$ & PROFI BETÓN, s.r.o. & spoločník 70\% (minulý), konatel' (minulý) & 2014 & $675931 €$ & $-189913 €$ \\
\hline E & $\mathbf{x}$ & International Investment Hotels Holding a. s. & predseda dozornej rady (minulý) & 2015 & $484393 €$ & $3666472 €$ \\
\hline E & $\mathbf{x}$ & International Investment Development Holding a. s. & Elen dozornej rady (minulý) & 2015 & $863 €$ & $-9890 €$ \\
\hline E & $\checkmark$ & BALAX s.r.o. & spoločník 100\% (súčasný), konateir (súČasný) & 2014 & $715050 €$ & $-56553 €$ \\
\hline EX & $\mathbf{x}$ & ESTRIN s.r.o. & spoločník 100\% (minulý), konateI (minulý) & 2015 & $82527 €$ & $-33415 €$ \\
\hline- & $x$ & PODKOLIBSKÁ, s.r.o. v likvidácii (zrušená) & spoločník 40\% (minulý), konatel' (minulý) & & & \\
\hline & $x$ & BS-FIN spol. s r.o. v likvidácii (zrušená) & spoločník 100\% (minulý) & & & \\
\hline B & $\mathbf{x}$ & B.A. Haus a. s. & člen predstavenstva (minulý) & 2015 & $292765 €$ & $125291 €$ \\
\hline E & $\mathbf{x}$ & FORUM GROUP TWO, a. s. & člen predstavenstva (súčasný) & 2015 & $0 €$ & $-1044 €$ \\
\hline (N) & $\checkmark$ & FULKRUM, s. r. o. & spoločník 30\% (minulý), konater' (minulý) & 2009 & $34 €$ & $-5589 €$ \\
\hline
\end{tabular}

Source: Own processing. 
Through the comparison with the competition we can obtain information about the development of incomes and profits, development of margin, the turnover period of liabilities and assets, profitability, liquidity, indebtedness. These comparisons are shown in Figure 12.

Figure 12: The comparison of the basic economic indicators with competition in application IndexPodnikatel'a

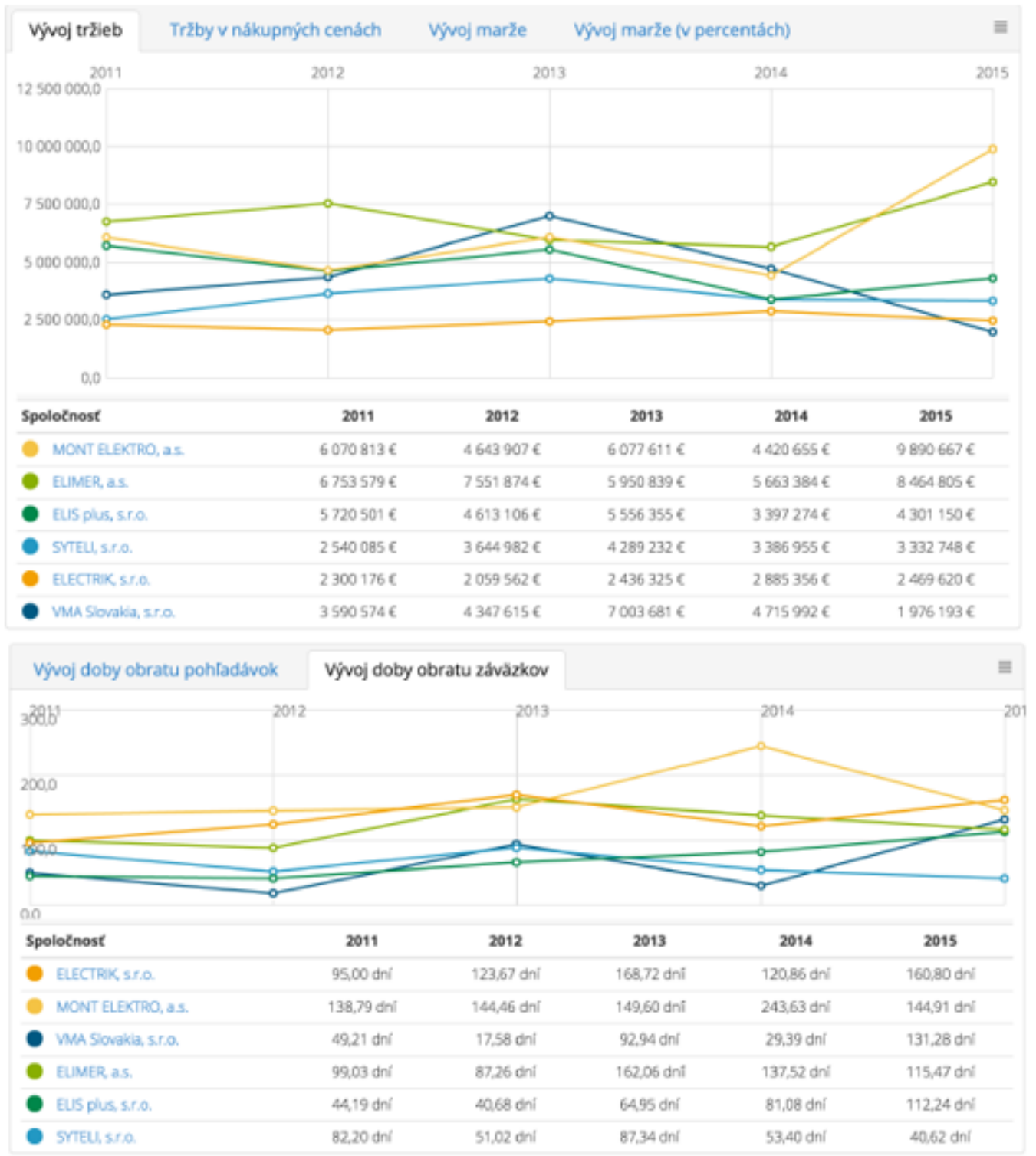

Source: Own processing.

With this application the company may also find new customers with the following information:

- websites, e-mails, phone contacts,

- filtering by company's legal form,

- filtering by residence (region, district, city),

- filtering by industry,

- search only uncontroversial companies,

- many other filters. 


\section{Conclusion}

We can point out in the conclusion that none of these applications does not have its version in English. FinStat application provides more information for free than IndexPodnikatel'a. In the FinStat application we can obtain free of charge information on sales, profits, incomes, assets, equity capital, gross margin, return of assets and the total debt of the observed company. But on the contrary in the applciation IndexPodnikatel'a we can receive information only about the development of sales and earnings. Both applications provide basic information about the establishment of the company, its field of business, registration number and information on whether the company has any debts and arrears. We can find the difference between applications also in filtering capabilities of searching information. This service si chareged in the application IndexPodnikatel'a. However, we must point out that IndexPodnikatel'a offers to its potential clients free access for 14 days to paid services.

The use of open data in corporate activities has got ascending tendency. If you want to carry business in the EU market, the portal European Union Open Data Portal is a very good source of information. To do business locally, it is advisable to find a data source in the country. In the SR is suitable for this purpose portal IndexPodnikatela. By providing easy and free access to data, the portal aims to promote their innovative use and unleash their economic potential.

\section{References}

Auer, S. R. et al; (2007). "DBpedia: A Nucleus for a Web of Open Data". The Semantic Web. Lecture Notes in Computer Science. 4825. p. 722. doi:10.1007/978-3-540-76298-0_52. ISBN 978-3-54076297-3.

Štofková, J. et al (2011). Manažment podniku. V Žiline : Žilinská univerzita. ISBN 978-80-554-0418-9.

Soltes, V., Stofkova, K. R. (2016). „THE IMPACT OF BUSINESS ENVIRONMENT ON REGIONAL DISPARITIES“. CBU International Conference Proceedings, ISSN: 1805-9961

John Wilbanks (2008). VP Science. Creative Commons

FinStat open data, online: <finstat.sk>

IndexPodnikatela open data, online: <indexpodnikatela.sk>

Open data Barometer, Rankings for Europe and Central Asia, online: < http://opendatabarometer.org/> Open definition, online: <http://opendefinition.org/> 